\title{
Clemência no Tribunal do Júri? Reflexões derivadas do argumento a fortiori trazido no voto-vogal do Min. Fachin em sede do ARE 1225185, Tema/RG 1.087
}

\author{
Jury nullification? Reflections derived from the \\ argumentum a fortiori brought by the opinion of Min. \\ Fachin on the ARE 1225185, Tema/RG 1.087
}

Hugo Soares $^{1}$

Universidade Humboldt, Berlim, Alemanha

hsoares14@gmail.com

lattes.cnpq.br/3831613931413684

orcid.org/0000-0003-2263-6432

\begin{abstract}
Resumo: O artigo busca responder a questão da legitimidade da absolvição por clemência no júri a partir da análise crítica do argumento a fortiori que sustenta sua inadmissibilidade no julgamento de crimes hediondos dolosos contra a vida, pois se nem ao Parlamento seria dado abdicar da punição muito menos estaria o Tribunal do Júri autorizado a tanto. Levanta-se a hipótese de que o Tribunal do Júri, de fato, não seja hierarquicamente inferior ao Parlamento, de modo que as premissas do argumento a fortiori estariam equivocadas. Procede-se a uma revisão bibliográfica baseada no funcionalismo penal a respeito da natureza jurídica do Tribunal do Júri no ordenamento jurídico e suas consequências dogmáticas, de modo a verificar a hipótese levantada. Observa-se que o júri consiste numa garantia institucional titularizada pelo Povo, o que permite concluir que ele é hierarquicamente superior ao Parlamento e que a clemência deve, então, ser vista como uma renúncia soberana à pena.
\end{abstract}

1 Doutorando em Direito Penal pela Universidade Humboldt de Berlim. Mestre em Direito e Ciência Jurídica (especialidade Direito Penal e Ciências Criminais) pela Universidade de Lisboa. Graduado em Direito pela Universidade Federal da Bahia, com um semestre de intercâmbio acadêmico na Universidade Paris VIII Vincennes - Saint-Denis. Advogado. 
Palavras-chave: Tribunal do Júri; clemência; garantia institucional; Povo; renúncia soberana à pena.

ABSTRACT: The paper aims to answer the problem of the legitimacy of the jury nullification through the critical analysis of the argumentum a fortiori that sustains its inadmissibility in trials of heinous crimes against life because if neither the Parliament would be allowed to waive punishment, much less would the Jury be authorized to do so. The paper raises the hypothesis that the Jury is indeed not hierarchically inferior to the Parliament, so that the premises of the argumentum a fortiori would be mistaken. A bibliographical review based on the criminal functionalism is carried out regarding the legal nature of the Jury Court in the legal system and its dogmatic consequences, in order to verify the raised hypothesis, which observes that that the Jury corresponds to an institutional guarantee belonging to the People, allowing us to conclude that it is hierarchically superior to the Parliament and that the Jury nullification should therefore be seen as a sovereign waiver of the punishment.

KEYWORDS: Jury; Jury nullification; institutional guarantee; People; sovereign waiver of the punishment.

SuMÁRıO: Introdução; 1 . O que é o Tribunal do Júri para a Constituição?; 1.1. O júri como garantia institucional; 1.2. O júri como manifestação direta do Povo; 2. O instituto da clemência no júri; 2.1. A clemência como renúncia soberana à pena; 2.2. As limitações do poder de disposição do júri sobre a pena; Conclusões; Referências bibliográficas.

\section{INTRODUÇÃO}

Bons argumentos não são apenas os que convencem, mas também aqueles que nos fazem, de fato, refletir. Eles abrem margem para que os debates dos quais participam sejam colocados nos devidos lugares e outros argumentos floresçam. É o caso do argumento a fortiori trazido pelo Min. Edson Fachin em seu voto-vogal elaborado para o julgamento do ARE 1225185, tema/RG 1.087. O problema jurídico a ser respondido é o da admissibilidade da chamada clemência no Tribunal do Júri, instituto 
que confere aos jurados o poder de absolver o réu ainda que as provas dos autos manifestamente demonstrem tanto a materialidade e autoria do delito, quanto seus elementos: tipicidade, antijuridicidade e culpabilidade. Posicionando-se contrariamente ao reconhecimento sem ressalvas desse instituto, o referido Ministro finaliza seu voto trazendo o seguinte argumento: "Ora, crimes hediondos, como dispõe a própria Constituição Federal, são insuscetíveis de graça ou anistia e, a fortiori, de clemência a cargo do Tribunal do Júri”.

Noutras palavras: se nem ao Parlamento é dado abdicar da punição a um crime hediondo, muito menos o Tribunal do Júri teria tal poder. Por trás dessa lógica reside, portanto, a ideia de superioridade hierárquica do Parlamento, representante do Povo por excelência, sobre outras instituições sociais. Trata-se de um caminho razoável. Caso o tomemos como premissa, a conclusão lógica que se impõe é exatamente aquela à qual o Min. Fachin chegou: o Tribunal do Júri não pode renunciar à pena por não ter legitimidade para tanto. E mais, ao trazer a ideia de superioridade do Parlamento - em conjunto com a sua proibição de renúncia à pena -, 0 Min. Fachin reposiciona dogmaticamente a discussão sobre a clemência. Ela sai do âmbito da Teoria do Delito - não raro colocada como o reconhecimento de uma causa supralegal de exclusão de culpabilidade ${ }^{2}-$, e passa a inserir-se, antes, nos campos da Teoria Constitucional - debates sobre o Povo e seus representantes - e da Teoria dos Direitos e Garantias Fundamentais - debates sobre sua natureza, titularidade e possibilidades de disposição. É a esse insight que o argumento a fortiori do Min. Fachin nos permite chegar: a clemência é um ato de abdicação da pena, não uma exclusão da culpabilidade, que nem o representante maior do Povo está constitucionalmente autorizado a praticar.

Um segundo caminho que podemos tomar como premissa, e que tentarei defender no presente artigo, é questionar essa pretendida superioridade hierárquica do Parlamento frente ao Tribunal do Júri. Noutras

2 Cf., por exemplo, FACCINI NETO, Orlando. A clemência e o Júri: uma tentativa de conciliação. In: FACCINI NETO, Orlando. Questões morais e direito penal: estudos reunidos (e-Pub). São Paulo: Saraiva, 2020, tópico 10.3. A classificação dogmática adequada da clemência será trabalhada oportunamente. 
palavras, buscarei, adotando uma metodologia funcionalista, ${ }^{3}$ sustentar a hipótese de que a intuição do senso-comum de que o Tribunal do Júri é o tribunal do Povo foi acolhida pelo Constituinte de 88 (I) para, posteriormente, analisar as consequências dogmáticas dessa percepção para reconhecimento do instituto da clemência (II).

\section{O QUE É O TRIBUNAL DO JÚRI PARA A CONSTITUIÇÃO?}

Os dois caminhos apontados na introdução são plausíveis e razoáveis. A decisão por seguir um ou outro é, portanto, uma opção político-criminal. ${ }^{4}$ As possibilidades de contribuição da ciência jurídica, nesse contexto, dividem-se em duas dimensões: (a) analisar criticamente qual opção seria mais conveniente num ordenamento ideal; ou (b) investigar qual foi a opção política do Constituinte. A primeira dimensão é relevante para auxiliar as escolhas feitas pelo Constituinte; a segunda, para colaborar com a interpretação constitucional, o que é o nosso caso. Meu argumento tentará mostrar que, ao elevar o reconhecimento da instituição do Tribunal do Júri à condição de norma fundamental (CF $5^{\circ}$ XXXVIII), o Constituinte optou por compreendê-lo como manifestação popular direta, como tribunal do Povo, de quem o poder emana (CF $1^{\circ} \S$ único).

\subsection{O JÚRI COMO GARANTIA INSTITUCIONAL}

O Tribunal do Júri não precisa ter um status jusfundamental. ${ }^{5}$ Ele não decorre daquilo que se poderia chamar de direito natural, nem

3 Cf. ROXIN, Claus. Política criminal e sistema jurídico-penal. Rio de Janeiro: Renovar, 2002.

4 Em sentido similar, cf. breve análise histórica do Tribunal do Júri em RODRIGUES, Paulo Gustavo. Redefinindo o trânsito em julgado a partir da soberania dos veredictos: a coisa julgada parcial no tribunal do júri. Revista Brasileira de Direito Processual Penal, Porto Alegre, v. 6, n. 2, 2020, p. 876 e ss. (881). Sobre a relação entre as decisões político-criminais e a sistematização do Direito Penal, cf. ROXIN, Claus. Política criminal e sistema jurídico-penal. Rio de Janeiro: Renovar, 2002.

5 Por jusfundamental, refiro-me ao rol de direitos e garantias fundamentais em sentido amplo. 
tampouco é um direito fundamental em sentido material, ${ }^{6}$ como a vida, a integridade física, a liberdade de consciência e outros direitos individuais clássicos. Importante para nós, porém, é que a Constituição de 1988 conferiu-lhe natureza jusfundamental. Trata-se de um ato de livre vontade do Constituinte que, independentemente de ser uma liberalidade, tem significado: ${ }^{7}$ uma norma jusfundamental é, antes de tudo, uma pretensão oponível aos Poderes Públicos. ${ }^{8}$ Desse fato é possível deduzir uma conclusão

6 Diferentemente do conceito material de crime, que guarda uma relação mais estreita com a legitimidade da criminalização, a ausência de fundamentalidade de um direito não retira a legitimidade de seu reconhecimento, haja vista o condicionamento a fatores extrajurídicos que os direitos fundamentais sofrem. Exemplo de um direito fundamental apenas formal seria o direito de porte de armas nos EUA, fruto do desenvolvimento histórico americano. Para uma introdução em português sobre a discussão da fundamentalidade material de um direito, bem como a associação de entre direitos fundamentais e fatores extrajurídicos, cf., citando outros autores, CANOTILHO, José Joaquim Gomes. Direito Constitucional. 6. ed. Coimbra: Almedina, 1993, p. 530 e ss.; MENDES, Gilmar Ferreira; BRANCO, Paulo Gonet. Curso de Direito Constitucional. 12. ed. (ePub). São Paulo: Saraiva, 2017, cap. 3, tópicos 4 e 5; SARLET, Ingo. A Eficácia dos Direito Fundamentais: Uma Teoria Geral dos Direitos Fundamentais na Perspectiva Constitucional. 12. ed. Porto Alegre: Livraria do Advogado, 2015, p. 99 e ss.

7 A natureza jusfundamental do Tribunal do Júri, junto com algumas de suas consequências, já foram notadas por Lenio Streck. Cf. STRECK, Lenio Luiz. Júri: pode um simples "não" levar à imediata prisão do réu? Disponível em: <https://www.conjur.com.br/2020-jan-30/senso-incomum-juri-simples-nao-levar-imediata-prisao-reu>. Acesso em: 02 mar. 2021. Sobre as consequências de conferir status jusfundamental a algo, convém rememorar a passagem d'O Senhor dos Anéis onde Pippin, após jurar lealdade a Denethor, regente de Gondor, ouve de Gandalf: "Remember that! For you are now sworn to his service. I do not know what put it into your head, or your heart, to do that. But it was well done. I did not hinder it, for generous deed should not be checked by cold counsel. (...) For there is another side to it. You are at his command; and he will not forget. Be wary still!". TOLKIEN. John R. R. The Return of the King. Quality Paperback Book Club, 2001, p. 32. Conselho similar cabe também ao Constituinte de 1988. Inserir o Tribunal do Júri no catálogo das normas jusfundamentais nada mais é do que lhe jurar lealdade: um ato de generosidade que não deve ser criticado friamente, mas, ainda assim, um ato que o vincula ao Júri, o que tem consequências.

8 BONAVIDES, Paulo. Curso de Direito Constitucional. 15. ed. São Paulo: Malheiros, 2004, p. 560 e ss. (561); FERRAJOLI, Luigi. Por Uma Teoria dos direitos e dos Bens Fundamentais. (ePub). Porto Alegre: Livraria do Advogado Editora, 2011, parte I, tópico 4.; KINGREEN, Thorsten; POSCHER, Ralf. Grundrechte 
tão simples quanto evidente: se o júri é uma garantia fundamental, ${ }^{9}$ seu titular, por lógica, não pode ser o Estado.

A pergunta sobre a titularidade dessa garantia permanece, no entanto, em aberto. Uma primeira aproximação apontaria que a instituição do júri serviria aos interesses do arguido. Dessa concepção parecem advir argumentos, como o defendido por Streck, no sentido de que o Tribunal do Júri, por ser uma garantia constitucional, ${ }^{10}$ não poderia se virar contra o réu. ${ }^{11} \mathrm{O}$ júri, assim, seria um direito do acusado, em consonância com a comum associação entre direitos fundamentais e o indivíduo (ou a dignidade da pessoa humana). Tal visão parece difícil de aceitar. Primeiro, pois não há garantias de que o julgamento por um corpo de jurados beneficiará o réu: trata-se de uma questão meramente empírica e não sei dizer se os acusados do caso Nardoni não teriam mais chances de absolvição caso não fossem submetidos ao julgamento por leigos, por exemplo. Segundo, e muito mais importante, é que, fosse o Tribunal do Júri um direito fundamental do acusado, a ele caberia, por força de sua autonomia, o direito de não exercitar tal garantia constitucional. ${ }^{12}$ Ocorre que - diferentemente da Constituição Americana, que, na sua Sexta Emenda, vincula expressamente o júri ao acusado, aceitando

Staatsrecht II. 36. ed. Heidelberg: C. F. Müller, 2020, p. 76 e ss.; MENDES, Gilmar Ferreira; BRANCO, Paulo Gonet. Curso de Direito Constitucional. 12. ed. (ePub). São Paulo: Saraiva, 2017, cap. 3, tópico 5.5.; SILVA, José Afonso da. Curso de Direito Constitucional Positivo. 25. ed. São Paulo: Malheiros, 2005, p. 175 e ss. (178).

9 Ainda que em sentido amplo.

10 Ressalve-se a distinção, por vezes feita na doutrina luso-brasileira, entre direitos e garantias fundamentais, que, porém, traz poucos efeitos práticos. Cf. debate em SARLET, Ingo. A Eficácia dos Direito Fundamentais: Uma Teoria Geral dos Direitos Fundamentais na Perspectiva Constitucional. 12. ed. Porto Alegre: Livraria do Advogado, 2015, p. 255 e ss. Defendendo a distinção, cf. BONAVIDES, Paulo. Curso de Direito Constitucional. 15. ed. São Paulo: Malheiros, 2004, p. 525 e ss.

11 STRECK, Lenio Luiz. Júri: pode um simples "não" levar à imediata prisão do réu? Disponível em: <https://www.conjur.com.br/2020-jan-30/senso-incomum-juri-simples-nao-levar-imediata-prisao-reu>. Acesso em: 02 mar. 2021.

12 Considerando esse argumento, sem tomar uma posição definida, cf. SARLET, Ingo. A Eficácia dos Direito Fundamentais: Uma Teoria Geral dos Direitos Fundamentais na Perspectiva Constitucional. 12. ed. Porto Alegre: Livraria do Advogado, 2015, p. 403 (nota 590). Reconhecendo um direito de renúncia ao 
a possibilidade de renúncia desse direito; e da Constituição Portuguesa, que, ao menos em parte, ${ }^{13}$ garante ao arguido o direito de requerer, ou não, o julgamento pelos pares (CRP $207^{\circ}$ 1) -, a nossa Constituição atribuiu competência absoluta ao Tribunal do Júri (CF $5^{\circ}$ XXXVIII d), retirando-o da esfera de disponibilidade do acusado. Uma tentativa de construir uma teoria da indisponibilidade do direito do réu ao júri muito provavelmente dependeria de argumentos paternalistas que dificilmente encontrariam guarida num ordenamento liberal. ${ }^{14}$ Mais coerente entender que, no ordenamento brasileiro, o Tribunal do Júri não foi instituído como um direito do acusado. ${ }^{15}$

A outra forma de associar o Tribunal do Júri a um direito individual seria compreendê-lo como um direito da vítima. Em que pese a recente e crescente inserção das considerações sobre a vítima no pensamento penal, ${ }^{16}$ tal esforço não parece compatível com o atual desenho constitucional brasileiro. ${ }^{17}$ Primeiro, pois parece difícil fundamentar um direito do ofendido de ver o acusado ser julgado por um tribunal menos propenso a uma aplicação técnica das normas jurídicas. Ademais, os dois argumentos que refutam a ideia do júri como um direito do réu permanecem intocados: nem há garantias de que o Tribunal do Júri será mais benéfico aos interesses vitimais, nem parece haver justificativa para

júri, cf. ARAS, Vladimir. Renúncia ao julgamento pelo júri no processo penal brasileiro. Custos Legis, vol. II, 2010.

13 A Constituição Portuguesa também confere à acusação o direito de requerer o julgamento pelo júri.

14 Sobre o paternalismo, cf. MARTINELLI, João Paulo Orsini. Paternalismo jurídico-penal. Tese de doutorado. Faculdade de Direito. Universidade de São Paulo. São Paulo, 2010, p. 96 e ss.

15 Em sentido contrário, RODRIGUES, Paulo Gustavo. Redefinindo o trânsito em julgado a partir da soberania dos veredictos: a coisa julgada parcial no tribunal do júri. Revista Brasileira de Direito Processual Penal, Porto Alegre, v. 6, n. 2, p. 873-910, 2020, p. 882 e ss.

16 Cf. recente e minucioso exame sobre a inserção da vítima no pensamento penal, sobretudo nas teorias da pena e suas consequências dogmáticas em GUIMARÃES NETO, Silvio Leite. Uma teoria da pena baseada na vítima. A busca pela satisfação do indivíduo vitimado como finalidade da pena. São Paulo: Marcial Pons, 2020.

17 O que não impede que reflexões críticas a esse desenho sejam feitas, mas as posiciona num contexto mais teórico-abstrato e de menor aplicabilidade imediata. 
que um tal direito não esteja abrangido pela esfera de disponibilidade do afetado pelo crime. Não há, de fato, impedimentos normativos para que o ordenamento venha a ser alterado para tornar-se compatível com um direito da vítima à satisfação penal de seu sofrimento: ${ }^{18} \mathrm{o}$ Tribunal do Júri, em que pese ter natureza de garantia fundamental, não é cláusula pétrea, pois apenas os direitos e garantias individuais o são (CF $60 \S 4^{\circ}$ IV). ${ }^{19}$ Atualmente, porém, essa compatibilidade não existe.

$\mathrm{O}$ insucesso das tentativas de vincular a garantia fundamental ao Tribunal do Júri a um indivíduo mostra as limitações de uma concepção exclusivamente individualista dos direitos fundamentais. A classificação do direito ao júri como uma garantia institucional - ou seja, como uma proteção constitucional de instituições consideradas fundamentais à sociedade e normas objetivas de organização social ${ }^{20}$ - parece mais adequada: em que pesem seus ainda precários reconhecimento e desenvolvimento na ciência constitucional, ${ }^{21}$ parece relativamente consensual afirmar que há

18 Faz-se necessário, porém, um debate sério e aprofundado a respeito de todas as consequências e todos os argumentos favoráveis e contrários ao reconhecimento desse direito da vítima. Posicionando-se contrariamente às teorias da pena orientadas à vítima, cf. GRECO, Luís. Strafjurist mit gutem Gewissen Kritik der opferorientierten Straftheorie. Goltdammer's Archiv für Strafrecht, 2020, p. 260 e ss.

19 Em sentido contrário, atribuindo aos direitos sociais a natureza de cláusula pétrea no regime da Constituição de 1988, cf. BONAVIDES, Paulo. Curso de Direito Constitucional. 15. ed. São Paulo: Malheiros, 2004, p. 636 e ss. (641 e ss.). Em outra direção, mas também oposta, e afirmando o caráter de direito individual do Tribunal do Júri, cf. NUCCI, Guilherme de Souza. Manual de Processo Penal e Execução Penal. 13. ed. (ePub). Rio de Janeiro: Forense, 2016, cap. XX, tópico 2.

Cf. BONAVIDES, Paulo. Curso de Direito Constitucional. 15. ed. São Paulo: Malheiros, 2004, p. 536 e ss. (537); MIRANDA, Jorge. Manual de Direito Constitucional. Tomo IV. 3. ed. Coimbra: Coimbra Editora, 2000, p. 72 e ss. (73).

21 Sobre o estado ainda relativamente precário da investigação a respeito das garantias institucionais, também cf. MAUNZ, Theodor; DÜRIG, Günter; HERDEGEN, Matthias (Org.): Grundgesetz. Kommentar. Munique: C.H. Beck, 2020, Art. 1, Abs., 3, nr. 29. Para um aprofundamento do tema das garantias institucionais e suas problemáticas, cf. ABEL, Gunther. Die Bedeutung der Lehre von den Einrichtungsgarantien für die Auslegung des Bonner Grundgesetzes Berlim: Dunckler \& Humblot, 1964; MAGER, Ute. Einrichtungsgarantien: Entstehung, Wurzeln, Wandlungen und grundgesetzgemäße Neubestimmung einer dogmatischen Figur des Verfassungsrechts. Tübingen: 
instituições constitucionalmente tuteladas contra o Legislador Ordinário, ainda que haja controvérsias a respeito da possibilidade de extração de um direito subjetivo a partir delas. ${ }^{22}$

\subsection{O JÚRI COMO MANIFESTAÇÃO DIRETA DO POVO}

O reconhecimento do júri como uma garantia institucional parece, de certa forma, esvaziar a questão sobre sua titularidade. Ocorre que, sem uma resposta a essa pergunta, também não há como saber se o Parlamento é ou não superior ao Tribunal do Júri. Creio que uma breve revisão de uma doutrina constitucional de feição contratualista ${ }^{23}$ pode nos ajudar a entender melhor, ao menos algumas garantias institucionais e, ao mesmo tempo, a resolver esse impasse. Entendendo a Constituição como o contrato social no qual o Povo abdica de parte de suas liberdades para (re)fundar o Estado, ${ }^{24}$ os direitos fundamentais em geral consistiriam em ressalvas ao novo poder estatal, em espaços livres de intervenção pública. Nada impede, porém, que o Povo inclua, nesse rol de ressalvas, mais do que somente direitos individuais propriamente ditos. É, por exemplo,

Mohr Siebeck, 2003. Para uma introdução em língua portuguesa, cf. BONAVIDES, Paulo. Curso de Direito Constitucional. 15. ed. São Paulo: Malheiros, 2004, p. 534 e ss.

22 Cf. SARLET, Ingo. A Eficácia dos Direito Fundamentais: Uma Teoria Geral dos Direitos Fundamentais na Perspectiva Constitucional. 12. ed. Porto Alegre: Livraria do Advogado, 2015, p. 255 e ss. Kingreen e Poscher parecem entender ser sempre possível extrair direitos subjetivos das garantias institucionais, cf. KINGREEN, Thorsten; POSCHER, Ralf. Grundrechte Staatsrecht II. 36. ed. Heidelberg: C. F. Müller, 2020, p. 42 e ss.

23 Sobre o contratualismo, classicamente, ROUSSEAU, Jean-Jacques. Du contrat social. Paris: Chez Mourer et Pinparé, 1797, p. 26 e ss.; na atualidade, por todos, OTT, Konrad. Moralbegründungen: zur Einführung. Hamburgo: Junius, 2001, p. 126 e ss. Convém relembrar que o Direito Penal, desde há muito, também é diretamente influenciado pelo pensamento contratualista, cf. BECCARIA, Cesare. Dos delitos e das penas. 4. ed. Lisboa: Fundação Calouste Gulbenkian, 2014, p. 63 e ss.

24 Neste sentido, entendendo o paradigma da democracia constitucional como "filho da filosofia contratualista", Ferrajoli defende que as constituições sejam a forma escrita e positivada dos contratos sociais. cf. FERRAJOLI, Luigi. Por Uma Teoria dos direitos e dos Bens Fundamentais. (ePub). Porto Alegre: Livraria do Advogado Editora, 2011, parte I, tópico 4. 
perfeitamente possível que o Povo, no pacto social de gênese - ou, no caso da Constituição de 88, de refundação - do Estado, reserve para si certas instituições que repute importantes.

Defendo que seja esse o caso do Tribunal do Júri. O Poder Constituinte Originário, quando da elaboração da nova constituição, optou como que por retirar os julgamentos dos crimes dolosos contra a vida da esfera estatal, garantindo ao Povo o poder de julgar diretamente tal categoria capital de delitos. O Tribunal do Júri é, assim, uma ressalva do Povo frente ao Estado; ${ }^{25}$ uma afirmação de que, em relação a certos crimes capitais, é ele quem vai analisar o caso concreto e decidir sobre a necessidade e conveniência da imposição de uma pena, convergindo com a intuitiva definição de Tribunal do Júri como tribunal popular, tribunal do Povo, de quem todo o poder emana (CF $1^{\mathrm{o}} \S$ único) ${ }^{26}$ Dessa lógica é possível deduzir justificações tanto para a soberania dos vereditos (CF $5^{\circ} \mathrm{XXX}-$ VIII c), quanto para a fixação da competência absoluta (CF $5^{\circ}$ XXXVIII d) do Tribunal do Júri. Tal concepção também explica a ausência do

25 Entendendo o Tribunal do Júri como "direito de participação do povo na atividade jurisdicional estatal”, sem, porém, adentrar na discussão sobre as categorias de direitos fundamentais, cf. NUCCI, Guilherme de Souza. Princípios Constitucionais Penais e Processuais Penais. 4. ed. (ePub). Rio de Janeiro: Forense, 2015, cap. V, tópico 1.3.5.1. Ressalve-se que o mesmo autor defende posição ao menos aparentemente contraditória, compreendendo o Tribunal do Júri como um direito e garantia individual, mas uma garantia à garanti do devido processo legal. Cf. NUCCI, Guilherme de Souza. Manual de Processo Penal e Execução Penal. 13. ed. (ePub). Rio de Janeiro: Forense, 2016, cap. XX, tópico 2.

26 Perspectiva não só compatível, como harmônica com as percepções clássicas sobre o Tribunal do Júri. Por todas, e entendendo o júri como uma instituição que "place la direction réelle de la société dans les mains des gouvernés ou d'une portion d'entre eux, et non dans celle des gouvernants. (...) [Il] place le peuple lui-même, ou du moins une classe de citoyens, sur le siège du juge. L'institution du jury met donc réellement la direction de la société dans les mains du peuple ou de cette classe. (...) [Il] est avant tout une institution politique; on doit le considérer comme une mode de la souveraineté du peuple (...)[Il] est le moyen le plus énergique de faire régner le peuple (...)", cf. TOCQUEVILLE, Alexis de. De la démocratie en Amérique. Tomo I e II. Breslávia: Nouvelles Lectures d'Antan, 2019, p. 269 e ss. (271 e ss.), convém esclarecer que Tocqueville distingue os júris democráticos - associados ao povo e observados nos EUA - dos aristocráticos - à época presentes na Inglaterra, nos quais somente uma classe podia participar; o júri brasileiro, por estar aberto a qualquer do povo (CPP $436 \S 1^{\circ}$ ), insere-se no grupo democrático. 
Tribunal do Júri no rol constitucional de órgãos do Poder Judiciário (CF 92), ${ }^{27}$ bem como a inclusão do $\S 1^{\circ}$ no art. $9^{\circ}$ do CPM, feita em 2017 , que afirmou a competência do Tribunal do Júri em crimes dolosos contra a vida praticado por militares. ${ }^{28}$

Levanta-se, com isso, uma interessante objeção a pretensões de imposição de um "controle mínimo de racionalidade" por parte do Judiciário, ao qual o Min. Fachin faz referência em seu voto: ao tomar o veredito do júri como uma expressão direta do Povo, tem-se a inversão de um didatismo estatal que - num criticável elitismo democrático, caracterizado pela desconfiança em relação ao Povo $^{29}$ - atribui ao Estado a tarefa de educar e conduzir a população, colocando as instituições democráticas acima do demos, como se elas tivessem a legitimidade para "empurrar a história" ${ }^{30}$ na direção de sua preferência. Compreender o júri como tribunal do Povo significa reverter esse fluxo didático: o Povo não mais (apenas) aprende com o Estado ou com as instituições democráticas, mas, antes, os ensina suas virtudes e valores. ${ }^{31}$ Reverte-se, em suma, a relação

27 Cf. CAVALCANTE SEGUNDO, Antonio de Holanda; SANTIAGO, Nestor Eduardo Araruna. Íntima convicção, veredictos dos jurados e o recurso de apelação com base na contrariedade à prova dos autos: necessidade de compatibilidade com um processo de base garantista. Revista Brasileira de Ciências Criminais, São Paulo, v. 116, 2015, tópico 3.

28 O Código Penal Militar continuou, porém, prevendo exceções à competência do Tribunal do Júri (CPM $\left.9^{\circ} \S 2^{\circ}\right)$, cuja constitucionalidade, embora discutível, é razoável, por tratar-se de crimes cometidos por militares das Forças Armadas em missões de Estado, ainda que em tempos de paz.

29 Para uma crítica mais densa, cf. SILVA, José Afonso da. Curso de Direito Constitucional Positivo. 25. ed. São Paulo: Malheiros, 2005, p. 126 e ss. (127).

30 Expressão do Min. Luís Roberto Barroso, ao defender um "papel iluminista" do Supremo Tribunal Federal. Cf. BARROSO, Luís Roberto. 'Operação Abafa' tenta barrar avanços do STF, escreve Barroso. Disponível em: <https:// www1.folha.uol.com.br/ilustrissima/2018/02/em-artigo-ministro-do-supremo-rebate-criticas-feitas-ao-tribunal.shtml>. Acesso em: 02 mar. 2021.

31 "The jury trial exemplifies the idea that lay citizens play a crucial role in helping institutions learn-about the impact of laws on individuals and neighborhoods, about the shifting meaning of offenses over time, and about the tensions between formal and substantive justice some cases reveal, all as nonelite citizens understand these. Legal systems without significant lay involvement lack the public knowledge relevant to the growth and sensitivity of the law. As important, they fail to convey to the public that this is so: In addition to the ones who know about the laws in a professional sense, justice requires the ones who know about the laws 
de desconfiança, ${ }^{32}$ prevalecendo a ideia de que as instituições também podem ser melhoradas pelo Povo, ao invés de apenas melhorá-lo. ${ }^{33}$

A renovação da perspectiva do júri como tribunal do Povo está, por óbvio, sujeita a críticas de diversas ordens. A mais fundamental de todas reside na própria ausência de definição do conceito de Povo. Sempre invocado para sustentar as mais variadas teses e legitimar distintas

as they affect them; this requires a devolution rather than a concentration of responsibility for the law of the land.". DZUR, Albert W. Punishment, Participatory Democracy, and the Jury. Nova York: Oxford University Press, 2012, p. 47.

32 Associando o júri a uma postura de suspeição contra o poder centralizado do Estado, cf. JACKSON, John D. Making Juries Accountable. The American Journal of Comparative Law, vol 50, n. 3, 2002, p. 477 e ss. Como expressão articulada dessa desconfiança: "The trend of our epoch up to this time has been consistently towards specialism and professionalism. We tend to have trained soldiers because they fight better, trained singers because they sing better, trained dancers because they dance better, specially instructed laughers because they laugh better, and so on and so on. The principle has been applied to law and politics by innumerable modern writers. Many Fabians have insisted that a greater part of our political work should be performed by experts. Many legalists have declared that the untrained jury should be altogether supplanted by the trained judge. (...) Now, it is a terrible business to mark a man out for the vengeance of men. But it is a thing to which a man can grow accustomed, as he can to other terrible things; he can even grow accustomed to the sun. And the horrible thing about all legal officials, even the best, about all judges, magistrates, barristers, detectives, and policemen, is not that they are wicked (some of them are good), not that they are stupid (several of them are quite intelligent), it is simply that they have got used to it. Strictly they do not see the prisoner in the dock; all they see is the usual man in the usual place. They do not see the awful court of judgment; they only see their own workshop. (...) Our civilization has decided, and very justly decided, that determining the guilt or innocence of men is a thing too important to be trusted to trained men. It wishes for light upon that awful matter, it asks men who know no more law than I know, but who can feel the things that I felt in the jury box. When it wants a library catalogued, or the solar system discovered, or any trifle of that kind, it uses up its specialists. But when it wishes anything done which is really serious, it collects twelve of the ordinary men standing round. The same thing was done, if I remember right, by the Founder of Christianity." Cf. CHESTERTON, Gilbert Keith. Tremendous Trifles. 3. ed. Londres: Methuen \& Co., 1909, p. 65 e ss.

Cf. DZUR, Albert W. Punishment, Participatory Democracy, and the Jury. Nova York: Oxford University Press, 2012, p. 43 e ss (45). Por meio da clemência, o júri pode indicar tanto circunstâncias que considere capazes de afastar a pena como punições que julgue excessivas. Sobre essas possibilidades, cf. JACKSON, John D. Making Juries Accountable. The American Journal of Comparative Law, vol 50, n. 3, 2002, p. 503 e ss (506 e ss.). 
ideologias, trata-se de um conceito que carece de univocidade e cujo manejo, portanto, é, no mínimo, complicado. ${ }^{34}$ Nada disso afasta a necessidade de seu emprego nas discussões constitucionais, não só por causa de seu papel como questão fundamental da democracia, ${ }^{35}$ mas sobretudo porque a Constituição faz uso do termo, colocando-o como fonte de todo o poder legítimo (CF $1^{\circ}$, § único).

Não pretendo aqui discutir se o Povo é uma realidade natural ou uma ficção jurídica ${ }^{36}$ nem tentar esboçar uma definição do que é Povo, pois haveria, nessas empreitadas, um sério risco de "encher de vãs palavras muitas páginas e de mais confusões as prateleiras," ${ }^{37}$ o que não seria conveniente para solucionar um debate mais concreto como a questão do júri. Mais sensato parece encontrar quais figuras representam a concretização constitucional do conceito de Povo, isto é, a quais figuras o Constituinte atribuiu o poder de expressar a vontade direta do Povo. O eleitorado (CF 14, caput), por exemplo, configura uma das variações mais clássicas e intuitivas das concretizações constitucionais do Povo. Nesse contexto, e retomando as já tecidas considerações a respeito do júri como garantia institucional oponível aos Poderes Públicos, há bons motivos para crer que o Constituinte optou por ver no Tribunal do Júri uma dessas concretizações. ${ }^{38}$

Também é possível opor à noção de tribunal popular a crítica à amostragem insuficiente do júri. A rigor, a ideia de amostragem guarda

34 Para um breve apanhado histórico dos diferentes usos do conceito de povo, cf. COMPARATO, Fábio Konder. Variações sobre o conceito de povo no regime democrático. Estudos Avançados, São Paulo, v. 11, n. 31, 1997, p. 213 e ss. Sobre as distintas acepções do conceito, cf. também BONAVIDES, Paulo. Ciência Política. 18. ed. São Paulo: Malheiros, 2011, p. 72 e ss. (79 e ss.).

35 Para uma análise dessa questão, cf. MÜLLER, Friedrich. Wer ist das Volk: Die Grundfrage der Demokratie - Elemente einer Verfassungstheorie VI. Berlin: Duncker \& Humblot, 1997.

36 Cf. LEISNER, Walter. Das Volk: Realer oder fiktiver Souverän? Berlin: Duncker \& Humblot, 2005.

37 VELOSO, Caetano. Livros. Livro. Polygram, 1997.

38 Em sentido convergente, entendendo o Tribunal do Júri como "exercício direto do poder popular”, cf. SILVA JARDIM, Eliete. Tribunal do Júri - absolvição fundada no quesito genérico: ausência de vinculação à prova dos autos e irrecorribilidade. Revista EMERJ, Rio de Janeiro, v. 18, n. 67, 2015, p. 20 e ss. 
uma certa conexão com a de representatividade, de modo que já haveria uma certa contradição em sequer empregá-la numa discussão a respeito de uma concretização constitucional do conceito de Povo. Mas a crítica que aqui formulo resume-se na seguinte ideia: a associação entre a figura idealizada do Povo e a figura concreta do corpo de jurados seria inviável, haja vista que um grupo de apenas sete pessoas ${ }^{39}$ seria excessivamente pequeno para corresponder à vontade direta do Povo. ${ }^{40}$

A primeira resposta a essa objeção reside na possibilidade de reformar a composição do júri. A Constituição, ao tratar do tema, não determinou uma quantidade específica de jurados, delegando expressamente ao Legislador Infraconstitucional a tarefa de organizar o Tribunal do Júri (CF, $5^{\circ}$, XXXVIII), o que permite uma correção, ao menos parcial, desse problema. Deve-se, ademais, notar que tal crítica está localizada num plano pré-positivo. Isto é, ainda que fosse aceita, ela afetaria apenas a legitimidade da opção constitucional - o que, de fato, não é pouca coisa -, mas não seria capaz de afetar nem a sua existência, nem a sua cogência. Ainda mais importante, é razoável reconhecer uma inevitável imperfeição das concretizações constitucionais do conceito de Povo. Por exemplo, se, de fato, o eleitorado consiste numa amostragem mais ampla do que o Tribunal do Júri, a sua legitimidade é, noutra dimensão, maculada pela tendência de estímulo à formação de classes profissionais de políticos, ${ }^{41} \mathrm{o}$ que, por conseguinte, abre margem para a inserção de interesses particulares - seja pela via econômica, seja por outras formas de poder - na formação da vontade democrática. Por sua vez, a insuficiência amostral do Tribunal do Júri é compensada tanto pela menor vulnerabilidade à infiltração de interesses pessoais na formação da vontade quanto pela sua randomização advinda do sistema de alistamento (CPP, 425 e ss.) e sorteio ${ }^{42}$ (CPP, 432 e

39 A rigor, o Tribunal do Júri é composto de por 26 pessoas: um juiz togado e por 25 jurados sorteados. É o Conselho de Sentença que é composto por sete membros. Cf. NUCCI, Guilherme de Souza. Manual de Processo Penal e Execução Penal. 13. ed. (ePub). Rio de Janeiro: Forense, 2016, cap. XX, tópico 14.2.

40 Nesse sentido, LOPES JR., Aury. Direito processual penal. 19. ed. (ePub). São Paulo: Saraiva, 2019, cap. XIII, tópico 3.9.

41 DZUR, Albert W. Punishment, Participatory Democracy, and the Jury. Nova York: Oxford University Press, 2012, p. 55.

42 Sobre as vantagens do uso de sorteios como forma de seleção, cf. WOLIN, Sheldon S. Norm and form. In: WOLIN, Sheldon S. Fugitive democracy: and 
ss.) de jurados - que também está sujeito a críticas, igualmente sanáveis, relativas a uma insuficiente aleatorização. ${ }^{43}$ Não desconheço que existam imperfeições mais incorretas que outras, ${ }^{44}$ o que afirmo é que, para além das questões sanáveis pela já aventada possibilidade de reforma, o problema amostral do júri não é tão grave a ponto de comprometer a sua correspondência à vontade popular, pois é condição para o saneamento de problemas de outras concretizações constitucionais do Povo.

A última crítica à concepção do júri como tribunal do Povo que tratarei reside no seu risco de nos conduzir a uma espécie de feudalismo moral. ${ }^{45}$ Tal alteração implicaria, em última análise, o fim do Estado como hoje o conhecemos, acarretando uma desestruturação da ordem social capaz de deflagrar graves retrocessos relativos aos índices de violência observados na espécie humana. ${ }^{46}$ Nessa linha, legitimar o Tribunal do Júri como vontade direta do Povo, retirando-o da esfera de controle e de

other essays. Nova Jersey: Princeton University Press, 2016, p. 86 e ss. (87); Para uma defesa um tanto problemática do emprego da aleatoriedade nas decisões públicas, cf. HARCOURT, Bernard E. Meditaciones postmodernas sobre el castigo: Acerca de los límites de la razón y de las virtudes de la aleatoriedad (una polémica y un manifiesto para el siglo XXI). Revista de Derecho Penal y Criminologia, Bogotá, n. 90, vol. XXXI, 2010, p. 38 e ss. Para críticas à forma supostamente viciada e não representativa de seleção decorrente da organização do júri no Brasil (e, portanto, sanável), bem como outras objeções ao instituto do júri em si, cf. LOPES JR., Aury. Direito processual penal. 19. ed. (ePub). São Paulo: Saraiva, 2019, cap. XIII, tópico 3.9.

43 Cf. LOPES JR., Aury. Direito processual penal. 19. ed. (ePub). São Paulo: Saraiva, 2019, cap. XIII, tópico 3.9.

44 Para uma crítica à equiparação de todas as imperfeições, cf. ASCENSÃO, José de Oliveira. Pessoa, Direitos Fundamentais e Direito da Personalidade. Revista Mestrado em Direito, Osasco, ano 6, n. 1, 2006, p. 153 e ss. (155).

45 Expressão de Jesse Prinz, cunhada ao reconhecer um dilema entre a imposição de valores a populações heterogêneas e a redução das jurisdições a pequenas comunidades morais dotadas de autonomia. Cf. PRINZ, Jesse. Constructive sentimentalism: legal and political implications. Nomos, Nova York, vol. 53, 2013, p. 15.

46 WRANGHAM, Richard. Killer Species. Daedalus, Cambridge, vol. 133, 2004, p. 30 e ss. Cf. também breve análise associando o processo de integração civilizacional à redução de violência em PINKER, Steven. A History of Violence; We're getting nicer every day. Disponível em: <https://newrepublic. com/article/64340/history-violence-were-getting-nicer-every-day>. Acesso em: 02 mar. 2021. 
uniformização das instâncias democráticas, poderia representar um passo para a desintegração do tecido social que compõe o Estado, pondo em perigo a indissolubilidade da unidade nacional (CF, $1^{\circ}$, caput).

A resposta que se dá ocorre em dois sentidos relativamente interconectados. Primeiramente, a própria instituição do júri estaria ainda sujeita a uma certa heterogeneidade sociomoral, ${ }^{47} \mathrm{o}$ que, se não afasta, ao menos mitiga a aproximação com um dos extremos de um longo espectro que vai desde a homogeneização ético-social forçada até a feudalização moral -, a ponto de não mais significar uma ameaça relevante à unidade nacional. Mais importante parece reconhecer que, dentro desse espectro, há um espaço de livre movimentação político-constitucional que autoriza uma opção por um modelo mais ou menos centralizado sem que isso represente algum perigo à existência do Estado. Trata-se de uma lógica similar à da distribuição de competências e atribuições entre os entes federativos: nos Estados Unidos, por exemplo, os estados são competentes para legislar em matéria penal, ao passo que, no Brasil, tal competência é privativa da União (CF, 22, I). Nenhum desses diferentes desenhos constitucionais, contudo, consiste em riscos graves à unidade nacional dos seus respectivos países. Do mesmo modo, adotar uma concepção do Tribunal do Júri como expressão direta do Povo não parece ter o condão de inaugurar um temido feudalismo moral.

\section{O INSTITUTO DA CLEMÊNCIA NO JÚRI}

Feita a devida análise a respeito da natureza popular do Tribunal do Júri, cabe, agora, examinar as repercussões dessas considerações para o reconhecimento do instituto da clemência pela ciência penal. Noutras

47 Cf. PRINZ, Jesse. Constructive sentimentalism: legal and political implications. Nomos, Nova York, vol. 53, 2013, p. 15. É possível, contudo, levantar uma razoável crítica a respeito da forma socialmente homogeneizante que a seleção de jurados apresenta no Brasil. Cf. LOPES JR., Aury. Direito processual penal. 19. ed. (ePub). São Paulo: Saraiva, 2019, cap. XIII, tópico 3.9. Essa homogeneização abre espaço para uma perigosa tendência de enviesamento dos jurados por considerações preconceituosas. Cf. JACKSON, John D. Making Juries Accountable. The American Journal of Comparative Law, vol 50, n. 3, 2002, p. 479 e ss. Tais objeções, no entanto, seriam sanáveis ou ao menos mitigadas por meio de reformas legais. 
palavras, faz-se necessário discutir a possibilidade e formatação da clemência, bem como suas circunstâncias.

\subsection{A CLEMÊNCIA COMO RENÚNCIA SOBERANA À PENA}

As tentativas de enquadramento dogmático da clemência enveredam-se, não raro, pela análise do ilícito culpável. ${ }^{48}$ Cuidam, em geral, de analisar se uma absolvição manifestamente contrária às provas dos autos decorreria de uma excludente supralegal de culpabilidade, construindo, por vezes, posicionamentos com base em doutrinas que orbitam o conceito de culpabilidade, como o chamado princípio da desculpa defendido por Palma ${ }^{49}$ ou a categoria dogmática da responsabilidade sustentada por Roxin e Greco. ${ }^{50}$ Defendo que uma concepção do júri como tribunal popular, se levada a sério, põe esse caminho em xeque. Procurar uma resposta para a natureza da clemência na dogmática do delito significa buscar na própria conduta criminosa uma justificação para a sua não punição. É tentar manter a análise exclusivamente no plano dos atos de conhecimento, negando ao Tribunal do Júri - concretização constitucional do Povo - a prática de atos de vontade. A vontade de simplesmente não punir.

Tal visão faria sentido caso entendêssemos o júri como ente estatal e não como concretização constitucional do conceito de Povo. Um ato de vontade do Estado - como a abstenção de impor uma sanção $a$ priori legítima que o Povo, seu mandante, entende cabível - requer uma justificativa perante seus representados. É preciso apresentar razões que os convençam, é preciso dar-lhes satisfação por meio de argumentos. Ao entendermos o Tribunal do Júri como manifestação direta do Povo, porém, tal necessidade desaparece. A clemência não é, portanto, o reconhecimento de uma ausência de culpabilidade no caso concreto, pois ela

48 Cf. FACCINI NETO, Orlando. A clemência e o Júri: uma tentativa de conciliação. In: FACCINI NETO, Orlando. Questões morais e direito penal: estudos reunidos (ePub). São Paulo: Saraiva, 2020, tópico 10.3.

49 PALMA, Maria Fernanda. O princípio da desculpa em Direito Penal. Coimbra: Almedina, 2005.

50 Sucintamente, cf. ROXIN, Claus; GRECO, Luís. Strafrecht Allgemeiner Teil. Bd I. 5. ed. Munique: C.H. Beck, 2020, p. 317. 
é, antes, uma renúncia soberana à pena, um ato de vontade popular, que motivado pelas mais variadas causas - abdica da imposição da punição que é infligida em seu nome. E, como ato de vontade soberana, a clemência não precisa de argumentos justificantes, pois emitido exatamente por aqueles a quem a justificação seria destinada: o Povo, concretizado, segundo as normas constitucionais, na figura do Tribunal do Júri. Em suma, a relação de representação exige somente que o representante explique ao representado o exercício de seu poder. O contrário não ocorre, pois o representado é soberano. Não é por outro motivo que, numa eleição, o eleitor não precisa justificar o seu voto e não é por outro motivo que a Constituição de 1988 garantiu a soberania dos vereditos do Tribunal do Júri (CF, $5^{\circ}$, XXXVIII, c). ${ }^{51} \mathrm{~A}$ partir desse fundamento é possível legitimar a redação legalmente determinada do chamado quesito genérico (CPP, $\left.483, \S 2^{\circ}\right)$ - "O jurado absolve o acusado?" -, em substituição a questões específicas de caráter mais técnico.

Quanto à classificação dogmática da clemência como renúncia soberana à pena, convém um parêntese para um breve aprofundamento. A renúncia soberana à pena é uma espécie do gênero causa de isenção de pena (Strafbefreiungsgründe). Nessa categoria são incluídos os benefícios jurídicos que, a despeito de não afetarem a tipicidade, ilicitude e culpabilidade de uma conduta, retiram a punibilidade de seu autor. ${ }^{52}$ Dentro dela, temos dois subgrupos: as causas de exclusão de pena (Strafausschließungsgründe), que abrangem as circunstâncias, anteriores ou concomitantes ao fato punível, capazes de isentar um indivíduo da sua punição; e as causas de não-aplicação da pena (Strafaufhebungsgründe), que também compreendem circunstâncias capazes de afastar a punição de um indivíduo, mas que tenham ocorrido posteriormente à prática do fato punível. ${ }^{53}$ No caso da clemência, trata-se, como dito, de uma renúncia soberana à pena por parte do seu titular último, o povo. Essa renúncia,

51 Também atribuindo à soberania popular o fundamento do sistema eleitoral e do sistema de júri, cf. TOCQUEVILLE, Alexis de. De la démocratie en Amérique. Tomo I e II. Breslávia: Nouvelles Lectures d'Antan, 2019, p. 271.

52 Cf. VON HIPPEL, Robert. Deutsches Strafrecht. Bd. 2. Berlim: Springer, 1971, p. 382 e ss.

${ }^{53}$ Cf. VON HIPPEL, Robert. Deutsches Strafrecht. Bd. 2. Berlim: Springer, 1971, p. 382 e ss. 
por óbvio, só ocorre no momento do julgamento, sendo, portanto, classificável como uma causa de não-aplicação da pena. Considerando as causas de não-aplicação de pena mais tradicionais - a prescrição e as diferentes formas de perdão ${ }^{54}$-, a clemência possui a peculiaridade de, mais do que não ser um ato estatal, ser um ato de vontade popular direta. Por essa razão, a classifiquei como uma renúncia soberana.

Essa constatação nos conduz a uma conclusão imperativa, mas que, diante de sua contundência, requer certa coragem para afirmá-la. Sendo a clemência um ato de renúncia soberana à pena, deduz-se a impossibilidade de controlar as motivações que a fundamentaram. Tal visão pode, inclusive, ser sustentada pela garantia constitucional ao sigilo das votações no Tribunal do Júri (CF, $5^{\circ}$, XXXVIII, b). ${ }^{55}$ Daí decorre a admissibilidade de teses moral e juridicamente repulsivas, como a erroneamente chamada legítima defesa da honra, ${ }^{56}$ por parte do júri ${ }^{57}$ - com a ressalva de que ele não pode aceitá-la enquanto excludente efetiva de ilicitude,

${ }^{54}$ Cf. VON HIPPEL, Robert. Deutsches Strafrecht. Bd. 2. Berlim: Springer, 1971, p. 551 e ss.

55 O sigilo das votações é, por certo, uma norma sujeita a críticas de ordem teórico-abstrata, por criar obstáculos ao acesso à fundamentação das decisões. Sobre uma possível incompatibilidade entre o júri e um direito à fundamentação de decisões, cf. GRECO, Luís. Strafprozesstheorie und materielle Rechtskra$f t$ : Grundlagen und Dogmatik des Tatbegriffs, des Strafklageverbrauchs und der Wiederaufnahme im Strafverfahrensrecht. Berlin: Duncker \& Humblot, 2015, p. 886 e ss.; JACKSON, John D. Making Juries Accountable. The American Journal of Comparative Law, vol 50, n. 3, 2002, p. 503 e ss. (510 e ss) e LOPES JR., Aury. Direito processual penal. 19. ed. (ePub). São Paulo: Saraiva, 2019, cap. XIII, tópico 3.9. Sua justificação, contudo, parece residir tanto numa garantia da soberania do júri - ao impedir o acesso e, por conseguinte, o controle das fundamentações - como numa garantia da independência do júri. Cf. JACKSON, John D. Op. cit., p. 494 e ss., Tais razões acabam respondendo a crítica, posta por Aury Lopes Jr, a respeito do não-gozo das garantias orgânicas da Magistratura por parte dos jurados. Cf. LOPES JR., Aury. Op. cit., cap. XIII, tópico 3.9.

56 Cuida-se da situação em que, numa situação de flagrância de adultério, o marido mata a esposa, o terceiro envolvido ou ambos.

57 Crítico à aceitação dessa categoria de teses, cf. FACCINI NETO, Orlando. A clemência e o Júri: uma tentativa de conciliação. In: FACCINI NETO, Orlando. Questões morais e direito penal: estudos reunidos (ePub). São Paulo: Saraiva, 2020, tópico 10.2. 
mas apenas como motivo relevante para a renúncia da pena. ${ }^{58}$ Noutras palavras, o argumento da defesa da honra - e teses similares - pode afastar a imposição da pena, a punibilidade, mas não tornar um ilícito justo. ${ }^{59}$

Uma solução para dificultar a ocorrência de tais situações seria vedar à defesa o direito de sustentar tais argumentos. Parece difícil, porém, fundamentar, como pretende o Min. Dias Toffoli na ADPF 779/ DF, uma nulidade processual ou uma proibição puramente jurídica de levantar tal espécie de tese defensiva, considerando a garantia constitucional da plenitude de defesa (CF, 5 XXXVIII a). A solução desse impasse residiria, talvez, na inserção de tais limitações no plano da ética advocatícia, ${ }^{60}$ por meio do reconhecimento de um dever do defensor de não apelar a argumentos moral e juridicamente repulsivos - dever talvez derivável dos art. 31 ou 34, VI ou XXV do EAOAB ou talvez somente fundamentável de lege ferenda (o que demonstra a necessidade de um estudo mais profundo e específico).

\subsection{AS LIMITAÇÕES DO PODER DE DISPOSIÇÃO DO JÚRI SOBRE A PENA}

A concepção que ora defendo não é completamente nova. Creio apenas que suas bases ainda não tenham sido devidamente explicitadas e levadas a sério, o que acabou impedindo - ou ao menos dificultando que extraíssemos as suas consequências da forma mais correta. É a partir dessa renovada fundamentação do Tribunal do Júri que se torna possível

58 Daí que seria mais correto chamar o argumento de tese da defesa da honra, excluindo a referência a ideias de legitimação. No mesmo sentido, cf. decisão, de relatoria do Min. Dias Toffoli que concedeu medida cautelar em sede da ADPF 779/DF.

59 O que é relevante para que a vítima possa requerer uma indenização no âmbito cível, pois apenas as sentenças penais que reconheçam alguma justificante legal fazem coisa julgada na esfera cível (CPP 65), sendo expressamente estabelecida a possibilidade de propositura de ação cível nos casos de decisões referentes à extinção da punibilidade (CPP 67 II), o que seria o caso da clemência. Em sentido contrário, FACCINI NETO, Orlando. A clemência e o Júri: uma tentativa de conciliação. In: FACCINI NETO, Orlando. Questões morais e direito penal: estudos reunidos (ePub). São Paulo: Saraiva, 2020, tópico 10.2.

60 Num sentido amplo que abarque também os defensores públicos. 
responder ao que chamo de argumento do cavalo de Tróia trazido por Trindade e Streck: a aceitação da clemência - por eles descrita como o "sim, porque sim" - esconderia consigo, tal qual um presente de grego, a necessidade de também acolhermos a condenação sem fundamentos - a que eles se referem como o "não, porque não". ${ }^{61}$ Não há insensatez nessa lógica, sobretudo por ela guardar uma certa conexão com o princípio da paridade de armas, ${ }^{62}$ que, por sua vez, pode ser derivado do princípio da igualdade (CF, $5^{\circ}$, caput).$^{63}$ No plano do Direito vigente, ${ }^{64}$ trata-se da principal objeção à clemência no júri, pois não parece haver, dentro do ordenamento brasileiro, outro óbice ao reconhecimento do instituto. ${ }^{65}$

O erro do argumento do cavalo de Tróia reside em ignorar ${ }^{66}$ não apenas a origem democrática do Tribunal do Júri, mas sobretudo a necessária distinção entre os princípios da democracia e do Estado de Direito

61 TRINDADE, André Karam; STRECK, Lenio Luiz. Júri não pode absolver porque quer ou porque sim. Nem condenar. Disponível em: https://www. conjur.com.br/2016-jun-18/diario-classe-juri-nao-absolver-porque-ou-porque-sim-nem-condenar. Acesso em: 02 mar. 2021.

${ }^{62}$ Nesse sentido, cf. FACCINI NETO, Orlando. A clemência e o Júri: uma tentativa de conciliação. In: FACCINI NETO, Orlando. Questões morais e direito penal: estudos reunidos (ePub). São Paulo: Saraiva, 2020, tópico 10.2. Convém ressaltar que, a rigor, a positivação constitucional da paridade de armas limita-se aos processos decorrentes de atos infracionais (CF $227 \S 3^{\circ} \mathrm{IV}$ ).

${ }^{63}$ Sobre a paridade de armas e sua relação com a igualdade, cf. VIEIRA, Renato Stanziola. Paridade de armas no processo penal: do conceito à aplicação no direito processual brasileiro. Dissertação de Mestrado. Faculdade de Direito. Universidade de São Paulo. São Paulo, 2013.

${ }^{64}$ Num plano mais crítico-abstrato, a objeção do direito da vítima ganha relevo.

${ }_{65}$ Mesmo seu fundamento legal pode ser extraído do chamado quesito genérico (CPP $483 \$ 2^{\circ}$ ), isto é, da possibilidade, estabelecida sem ressalvas, de absolvição do réu mesmo após o reconhecimento da autoria e da materialidade do delito. Admitindo tal interpretação e mencionando expressamente a inexistência de uma "exigência de accountability", cf. TRINDADE, André Karam; STRECK, Lenio Luiz. Júri não pode absolver porque quer ou porque sim. Nem condenar. Disponível em: https://www.conjur.com.br/2016-jun-18/ diario-classe-juri-nao-absolver-porque-ou-porque-sim-nem-condenar. Acesso em: 02 mar. 2021.

${ }^{66}$ Nota-se essa confusão em Trindade e Streck quando, após rechaçarem um modelo que permita a condenação sem provas, clamam por uma "dose de democracia”, quando o mais técnico seria pedir por mais Estado de Direito. Cf. TRINDADE, André Karam; STRECK, Lenio Luiz. Júri não pode absolver porque quer ou porque sim. Nem condenar. Disponível em: https://www.conjur. 
(CF, $1^{\circ}$, caput $) .{ }^{67}$ Enquanto a ideia de Estado de Direito vincula-se às de direitos fundamentais, constitucionalidade e juridicidade, associando-se a imperativos de justiça, ${ }^{68}$ o princípio democrático está conectado ao conceito de Povo e soberania popular, ligados a questões de poder e próximos da noção de vontade geral. ${ }^{69}$ Em última análise, trata-se

com.br/2016-jun-18/diario-classe-juri-nao-absolver-porque-ou-porque-sim-nem-condenar. Acesso em: 02 mar. 2021..

67 A distinção entre os princípios da democracia e do Estado de Direito guarda paralelos e similiaridades com a distinção entre os modelos de autoridade coordenado - caracterizado por estruturas de autoridade definidas por leigos aplicando valores comunitários nas decisões públicas - e hierárquico identificado por um corpo profissional inserido numa cadeia de comando e orientado a promover decisões baseadas em critérios técnicos. Sobre os referidos modelos, cf., minuciosamente, DAMAŠKA, Mirjan. Structures of Authority and Comparative Criminal Procedure. The Yale Law Journal, New Haven, vol. 84, n. 3, 1975, p. 483 e ss.; de forma sucinta, cf. JACKSON, John D. Making Juries Accountable. The American Journal of Comparative Law, vol 50, n. 3, 2002, p. 477 e ss. (478 e ss.). Uma notável convergência entre essas duas distinções reside exatamente na conclusão favorável à possibilidade de o Tribunal do Júri ignorar a lei para absolver, mas não para condenar um réu. A análise dessa possibilidade sob a ótica dos princípios da democracia e do Estado de Direito será promovida aqui. Para uma análise sob a perspectiva dos modelos de autoridade, cf. JACKSON, John D. Op. cit., p. 512 e ss. (517).

CANOTILHO, José Joaquim Gomes. Direito Constitucional. 6. ed. Coimbra: Almedina, 1993, p. 348 e ss. (380 e ss.). Não por acaso, são atribuídas a Kant as primeiras formulações concretas que desembocariam no conceito de Estado de Direito: as expressões “condição jurídica” ou mesmo "estado jurídico” [com "e" minúsculo] (rechtlicher Zustand ou status iuridicus), que representam uma condição na qual todos os indivíduos teriam seus direitos assegurados. Cf. BYRD, B. Sharon; HRUSCHKA, Joachim. Kant zu Strafrecht und Strafe im Rechtsstaat. Juristen Zeit, Tubinga, ano 60, n. 20, 2007, p. 958; KANT, Immanuel. Über den Gemeinspruch: Das mag in der Theorie richtig sein, taugt aber nicht für die Praxis. AA VIII, 1793, p. 292.

CANOTILHO, José Joaquim Gomes. Direito Constitucional. 6. ed. Coimbra: Almedina, 1993, p. 401 e ss. Sobre a ideia de vontade geral e sua natureza de "direção suprema", cf. ROUSSEAU, Jean-Jacques. Du contrat social. Paris: Chez Mourer et Pinparé, 1797, p. 26 e ss. (30 e ss.). Sobre as limitações da democracia, é possível notar, já na sua descrição aristotélica como forma corrompida da politeia - para Aristóteles, o governo virtuoso da maioria, a menos capaz forma virtuosa de governo -, que há um reconhecimento das suas falhas e de sua dissociação com a ideia de justiça, reconhecimento que funciona, porém, como uma "defesa qualificada" do governo da maioria, pois, considerando a corruptibilidade humana e, por conseguinte, de todos os governos, a democracia acaba sendo também a menos capaz forma viciada de 
da clássica relação de tensão entre os interesses coletivos (princípio democrático) e os interesses individuais (princípio garantístico, ${ }^{70}$ sobretudo na dimensão de respeito aos direitos fundamentais), que permeiam qualquer discussão sobre a organização social. O Estado Democrático de Direito é, assim, o modelo de Estado que tenta conciliar essas duas forças fundantes $^{71}$ - justiça e poder; indivíduo e coletivo - que, se nem sempre são antagônicas, não deixam de, em diversos momentos, se contrapor uma à outra. ${ }^{72}$ Distinguir esses dois princípios nos permite uma melhor visualização dos argumentos que estão em jogo nesses conflitos, bem como seu melhor manejo.

O Tribunal do Júri, dessa forma, significa o interesse do Povo de gerenciar a imposição da pena. A soberania dos vereditos (CF, $5^{\circ}$, XXXVIII, c), para ser uma real soberania, pressupõe o poder de renúncia dessa imposição. Ela incide, porém, somente sobre aquilo de que o Povo dispõe: o poder de punir. Num paralelo, a soberania está para o Povo assim como a autonomia está para o indivíduo: ambas significam a legitimação do exercício do autogoverno, e ambas são limitáveis pela existência de outros autogovernos igualmente legítimos. O titular desse

governo. Cf. RUSSELL, Bertrand. History of Western Philosophy. Abingdon: Routledge, 2004, p. 179 e ss. (183). Ressalve-se que, no Brasil, Paulo Bonavides chama a politeia de "democracia" e a democracia de "demagogia", o que pode provocar uma certa confusão. Cf. BONAVIDES, Paulo. Ciência Política. 18. ed. São Paulo: Malheiros, 2011, p. 208 e ss.

70 Expressão que Luís Greco utilizou para traduzir o adjetivo alemão "rechtstaatlich" - que significa "relativo ao Estado de Direito" - para o português. Cf. ROXIN, Claus. Política criminal e sistema jurídico-penal. Rio de Janeiro: Renovar, 2002, p. 3, nota 3.

71 Em sentido relativamente próximo, mas sem fazer uma distinção tão clara entre os dois princípios - por aglutiná-los num amplo princípio democrático (contribuindo para a tendência de criar cada vez mais adjetivos e qualificações para o conceito de democracia, o que acaba esvaziando o seu significado), que se subdividiria em duas dimensões: uma política (ou formal) e uma substancial -, cf. FERRAJOLI, Luigi. Por Uma Teoria dos direitos e dos Bens Fundamentais. (ePub). Porto Alegre: Livraria do Advogado Editora, 2011, parte I, tópico 4.

72 Para um aprofundamento da discussão sobre o conflito entre os princípios democrático e garantístico no âmbito do Direito Penal (sobretudo na discussão do conceito material de crime), cf. ROXIN, Claus; GRECO, Luís. Strafrecht Allgemeiner Teil. Bd I. 5. ed. Munique: C.H. Beck, 2020, p. 80 e ss. 
poder de punir, portanto, não está autorizado a decidir sobre aquilo que nunca lhe pertenceu: ${ }^{73}$ os direitos fundamentais do indivíduo, dentre os quais figura o direito ao devido processo legal (CF, $5^{\circ}$, LIV) - e, no plano de fundo, a própria liberdade de locomoção $\left(\mathrm{CF}, 5^{\circ}, \mathrm{XV}\right) \cdot{ }^{74} \mathrm{E}$, diga-se, não basta ao conceito de devido processo legal que o processo esteja submetido a um regramento editado pelo Parlamento. Antes, é necessário que esse regramento seja devido, isto é, justo. ${ }^{75}$ Certamente a discussão sobre o que é justiça é muito maior do que o escopo do presente texto ${ }^{76}$ porém é possível afirmar com segurança que a condenação sem provas - ou, pior, contrária às provas - consiste numa injustiça. Violaria, portanto, o chamado fair trial, ${ }^{77}$ corolário do devido processo legal.

73 Para uma fundamentação um pouco distinta da mesma ideia, recorrendo ao argumento de que os juízos absolutórios estão abertos também ao Direito Penal do Autor, enquanto os juízos condenatórios estão circunscritos apenas ao Direito Penal do Fato, cf. SILVA JARDIM, Eliete. Tribunal do Júri - absolvição fundada no quesito genérico: ausência de vinculação à prova dos autos e irrecorribilidade. Revista EMERJ, Rio de Janeiro, v. 18, n. 67, 2015, p. 14 e ss. (16 e ss.). Trata-se, porém, de um argumento intermediário que, embora pertinente, não é, a rigor, necessário, pois as razões pelas quais os juízos condenatórios devem ater-se ao Direito Penal do Fato e os juízos absolutórios estão livres para promover considerações de Direito Penal do Autor são justamente os princípios do Estado do Direito e da democracia, respectivamente.

É possível também mencionar o princípio da legalidade e da presunção de inocência. Cf. SILVA JARDIM, Eliete. Tribunal do Júri - absolvição fundada no quesito genérico: ausência de vinculação à prova dos autos e irrecorribilidade. Revista EMERJ, Rio de Janeiro, v. 18, n. 67, 2015, p.14 e ss. (17).

Associando o princípio do devido processo legal a uma "forma de assegurar a justa aplicação da força estatal na repressão aos delitos existentes”, cf. NUCCI, Guilherme de Souza. Princípios Constitucionais Penais e Processuais Penais. 4. ed. (ePub). Rio de Janeiro: Forense, 2015, cap. II, tópico 2.

76 Para uma introdução a esse debate, cf. SANDEL, Michael J. Justice: what's the right thing to do? Nova York: Farrar, Straus and Giroux, 2009.

77 A nível de crítica mais teórico-abstrata, é cabível questionar se o Tribunal do Júri, sobretudo no desenho brasileiro, não traz consigo um problema de valoração de provas e fundamentação das decisões que o torna inerentemente incompatível com um julgamento justo. Neste sentido, cf. GRECO, Luís. Strafprozesstheorie und materielle Rechtskraft: Grundlagen und Dogmatik des Tatbegriffs, des Strafklageverbrauchs und der Wiederaufnahme im Strafverfahrensrecht. Berlin: Duncker \& Humblot, 2015, p. 886 e ss.; e LOPES JR., Aury. Direito processual penal. 19. ed. (ePub). São Paulo: Saraiva, 2019, cap. XIII, tópico 3.9. A Constituição, ao instituir o júri como garantia fundamental, parece, porém, ter respondido negativamente a essa questão. Corrobora 
É também do reconhecimento desse embate entre o princípio do Estado de Direito e o fundamento democrático do Tribunal do Júri que se extrai a justificação para a garantia constitucional da plenitude de defesa nos processos de competência do júri (CF, $5^{\circ}, \mathrm{XXXVIII,} \mathrm{a),}{ }^{78}$ algo que vai além da usual ampla defesa garantida em todos os processos judiciais e administrativos $\left(\mathrm{CF}, 5^{\circ}, \mathrm{LV}\right) .{ }^{79} \mathrm{Tal}$ percepção é relevante não apenas para afastar o argumento do cavalo de Tróia, mas também para legitimar um direito de clamar expressamente pela clemência dos jurados. ${ }^{80}$

esse entendimento o dever constitucional de fundamentação das decisões judiciais (CF 93, IX), que é imposto aos órgãos do Poder Judiciário (CF 92), conjunto que não abrange o Tribunal do Júri - embora inclua implicitamente o juiz-presidente do júri, na medida em que é juiz estadual (CF 92, VII) ou federal (CF 92, III). Cf. CAVALCANTE SEGUNDO, Antonio de Holanda; SANTIAGO, Nestor Eduardo Araruna. Íntima convicção, veredictos dos jurados e o recurso de apelação com base na contrariedade à prova dos autos: necessidade de compatibilidade com um processo de base garantista. Revista Brasileira de Ciências Criminais, São Paulo, v. 116, 2015, tópico 3.

78 Em sentido similar, NUCCI, Guilherme de Souza. Princípios Constitucionais Penais e Processuais Penais. 4. ed. (ePub). Rio de Janeiro: Forense, 2015, cap. $\mathrm{V}$, tópico 1.1.3.

79 Alertando para a distinção entre ampla defesa e plenitude de defesa, cf. FACCINI NETO, Orlando. A clemência e o Júri: uma tentativa de conciliação. In: FACCINI NETO, Orlando. Questões morais e direito penal: estudos reunidos (ePub). São Paulo: Saraiva, 2020, tópico 10.1.; de forma um pouco mais aprofundada e citando outros autores, NUCCI, Guilherme de Souza. Manual de Processo Penal e Execução Penal. 13. ed. (ePub). Rio de Janeiro: Forense, 2016, cap. IV, tópico 3.1.3; idem. Princípios Constitucionais Penais e Processuais Penais. 4. ed. (ePub). Rio de Janeiro: Forense, 2015, cap. V, tópico 1.1.3. Utilizando a plenitude da defesa como argumento para justificar o direito do réu de renunciar ao Tribunal do Júri, cf. ARAS, Vladimir. Renúncia ao julgamento pelo júri no processo penal brasileiro. Custos Legis, vol. II, 2010, p. 6 e ss. Tal posicionamento parece equivocado por esquecer que o fundamento da plenitude de defesa é a submissão a um tribunal popular. Ou seja, a tese da possibilidade de renúncia ao júri confunde a plenitude de defesa no Tribunal do Júri, prevista constitucionalmente, com uma inexistente plenitude de defesa dos crimes dolosos contra a vida.

80 Direito cuja existência é defendida por Orlando Faccini Neto, embora posicionando-se contrariamente à clemência não requerida. FACCINI NETO, Orlando. A clemência e o Júri: uma tentativa de conciliação. In: FACCINI NETO, Orlando. Questões morais e direito penal: estudos reunidos (ePub). São Paulo: Saraiva, 2020, tópico 10.3. 
Se levada a sério, a plenitude de defesa no Tribunal do Júri, sobretudo em conjunto com a garantia de um devido processo legal, nos permite, para além de questões relativas à figura da clemência, questionar a própria constitucionalidade da vedação a uma segunda apelação nos casos em que o corpo de jurados novamente condenam o réu de forma manifestamente contrária $^{81}$ às provas dos autos (CPP, 593, $\left.3^{\circ}\right)$. Uma condenação sem provas permanece, afinal, uma condenação sem provas. A confirmação, por si só, de um juízo condenatório que se oponha de forma manifesta às provas produzidas não é capaz de torná-lo justo, pois a mera repetição não é critério de justiça. Um Estado que aceita a proibição sem ressalvas da segunda apelação no júri, portanto, aceita também a possibilidade de retirar a liberdade de inocentes por mero exercício do poder popular. É, ainda, um Estado Democrático, mas não mais um Estado de Direito.

Uma solução para preservar a constitucionalidade do dispositivo talvez consistisse em acolher a possibilidade de absolvição do réu nos casos de procedência da apelação, já que haveria um reconhecimento expresso, por parte do Judiciário, de que as provas produzidas contra o acusado não são capazes de sustentar uma condenação. Seria, também, uma forma de exigir responsabilidade do Povo por sua decisão. Caso ele não se atenha ao dever de julgamento justo - o que seria um abuso do poder de punir -, perde o direito de julgar. Seria uma conciliação entre os princípios democrático e garantístico..$^{82}$ A fundamentação legal para

81 A respeito das implicações recursais da admissão da clemência no Tribunal do Júri, convém um breve parêntese. O reconhecimento do instituto não impede a apelação contra absolvição manifestamente contrária ao conjunto probatório (CPP 593, III, b), pois somente a decisão absolutória decorrente do quesito genérico (CPP $483 \S 2^{\circ}$ ) pode ser classificada como uma irrecorrível renúncia soberana à pena, ou seja, um ato de vontade que independe da realidade fática. Permanece, contudo, disponível à acusação o recurso contra as absolvições que, em flagrante incongruência com as provas do processo, não reconhecem a materialidade ou a autoria do delito (CPP $483 \S 1^{\circ}$ ), pois se trata de atos de conhecimento, que devem vincular-se aos fatos, isto é, às provas colhidas. Para um maior aprofundamento nessa questão, cf. SILVA JARDIM, Eliete. Tribunal do Júri - absolvição fundada no quesito genérico: ausência de vinculação à prova dos autos e irrecorribilidade. Revista EMERJ, Rio de Janeiro, v. 18, n. 67, 2015, p. 20 e ss.

82 Essa solução talvez responda parcialmente a relevante questão levantada e deixada em aberto por Paulo Bonavides sobre se as garantias institucionais 
tanto possivelmente residiria numa interpretação a contrario sensu da própria vedação à segunda apelação. O Tribunal de Justiça, ao identificar uma contrariedade manifesta às provas, teria, a rigor, duas opções: ou absolver o réu ou submetê-lo a um novo júri. Ocorre que esse novo júri seria, nesse desenho, incompatível com a garantia constitucional da defesa plena (CF, 5 ${ }^{\circ}$, XXXVIII, a), já que não haveria a possibilidade de apresentar recurso contra uma segunda condenação contrária às provas, isto é, contra uma condenação injusta. Restaria ao Tribunal de Justiça, portanto, apenas a alternativa absolutória. A segunda apelação seria, então, vedada, pois caberia ao Tribunal de Justiça apenas reafirmar a vinculação do júri às provas ou absolver o réu. Teríamos algo como uma despronúncia tardia, um novo juízo de impronúncia, que talvez não tarde tanto a ponto de falhar. Tal sugestão, contudo, teria que ser discutida mais a fundo, sobretudo a sua compatibilidade com a soberania do Tribunal do Júri (CF $5^{\circ} \mathrm{XXXVIII} \mathrm{c),} \mathrm{o} \mathrm{que} \mathrm{não} \mathrm{cabe} \mathrm{no} \mathrm{presente} \mathrm{texto.}$

\section{CONCLUSÕES}

O debate sobre a clemência no Tribunal do Júri deve partir de análises no âmbito das Teorias Constitucional e dos Direitos e Garantias Fundamentais. O entendimento do júri como tribunal do Povo é, nesse contexto, fruto de uma opção político-criminal de conferir-lhe status de norma jusfundamental, tornando-o uma pretensão oponível aos Poderes Públicos.

Dentro do atual desenho constitucional brasileiro, porém, não é possível entender o Tribunal do Júri nem como um direito do acusado, nem como um direito da vítima, restando a possibilidade de compreendê-lo como uma garantia institucional. Numa doutrina constitucional de feição contratualista, o júri pode, então, ser visto como uma ressalva do Povo frente ao Estado, uma contraposição a um elitista e desconfiado didatismo estatal.

As possíveis objeções relativas à ausência de uma definição do conceito de Povo podem ser respondidas com o recurso à ideia de que o 
Tribunal do Júri se trata de uma de suas formas de concretização constitucional. Igualmente, às críticas a respeito de uma amostragem insuficiente do júri opõe-se o argumento da inevitável imperfeição das concretizações constitucionais do conceito de Povo. Por fim, receios de que o Tribunal do Júri representaria um passo na direção de um feudalismo moral são afastados sob o argumento de que a instituição do júri está inserida num espaço de livre movimentação político-constitucional.

A possibilidade e formatação da clemência têm origem no reconhecimento de que o Tribunal do Júri, como tribunal do Povo, é capaz de emitir atos de vontade, entre eles o ato de renúncia soberana à pena, que é a adequada classificação dogmática do instituto. A problemática admissibilidade de teses moral e juridicamente repulsivas - como a da legítima defesa da honra -, que se extrai dessa fundamentação, parece ser solucionável no âmbito da ética advocatícia - o que requer, todavia, um exame mais detido. $\mathrm{O}$ argumento do cavalo de Tróia - no sentido de que a renúncia à pena implicaria também a renúncia a um julgamento justo -, por sua vez, falha ao não compreender a distinção entre os princípios da democracia e do Estado de Direito. Enquanto o princípio democrático fundamenta a renúncia à pena, o garantístico assegura o respeito aos direitos individuais, incluindo a garantia ao devido processo legal.

É deste fundamento que se deduz a garantia constitucional à plenitude de defesa, de onde também se extraem dúvidas a respeito da constitucionalidade da vedação a uma segunda apelação em casos de condenação manifestamente contrária às provas dos autos. Para sanar esse problema, sugeri o acolhimento de uma possibilidade de despronúncia tardia por parte dos Tribunais de Justiça, cuja discussão merece mais aprofundamentos.

Ao fim de tudo, gostaria de retomar às considerações que deram início a esse texto. Como espero ter exposto, o argumento a fortiori do Min. Fachin não é capaz de convencer que a clemência seja um instituto vedado ao Tribunal do Júri. É, porém, um bom argumento. Bom, porque nos abriu um espaço para reflexão e crítica. Bom, porque nos deu a oportunidade para recolocar a discussão sobre o Tribunal do Júri em seu devido lugar: no debate sobre o papel do Povo na administração da justiça penal e suas consequências. Bom, enfim, porque belo. 


\section{REFERÊNCIAS BIBLIOGRÁFICAS}

ABEL, Gunther. Die Bedeutung der Lehre von den Einrichtungsgarantien für die Auslegung des Bonner Grundgesetzes Berlim: Dunckler \& Humblot, 1964. https:// doi.org/10.3790/978-3-428-40001-0

ARAS, Vladimir. Renúncia ao julgamento pelo júri no processo penal brasileiro. Custos Legis, vol. II, 2010.

ASCENSÃO, José de Oliveira. Pessoa, Direitos Fundamentais e Direito da Personalidade. Revista Mestrado em Direito, Osasco, ano 6, n. 1, 2006.

BARROSO, Luís Roberto. 'Operação Abafa' tenta barrar avanços do STF, escreve Barroso. Disponível em: <https://www1.folha.uol.com.br/ilustrissima/2018/02/ em-artigo-ministro-do-supremo-rebate-criticas-feitas-ao-tribunal.shtml $>$. Acesso em: 02 mar. 2021.

BECCARIA, Cesare. Dos delitos e das penas. 4. ed. Lisboa: Fundação Calouste Gulbenkian, 2014.

BONAVIDES, Paulo. Ciência Política. 18. ed. São Paulo: Malheiros, 2011.

BONAVIDES, Paulo. Curso de Direito Constitucional. 15. ed. São Paulo: Malheiros, 2004.

BYRD, B. Sharon; HRUSCHKA, Joachim. Kant zu Strafrecht und Strafe im Rechtsstaat. Juristen Zeit, Tubinga, ano 60, n. 20, 2007. https://doi. org/10.1628/002268807782338547

CANOTILHO, José Joaquim Gomes. Direito Constitucional. 6. ed. Coimbra: Almedina, 1993.

CAVALCANTE SEGUNDO, Antonio de Holanda; SANTIAGO, Nestor Eduardo Araruna. Íntima convicção, veredictos dos jurados e o recurso de apelação com base na contrariedade à prova dos autos: necessidade de compatibilidade com um processo de base garantista. Revista Brasileira de Ciências Criminais, São Paulo, v. 116, 2015.

CHESTERTON, Gilbert Keith. Tremendous Trifles. 3. ed. Londres: Methuen \& Co., 1909.

COMPARATO, Fábio Konder. Variações sobre o conceito de povo no regime democrático. Estudos Avançados, São Paulo, v. 11, n. 31, 1997. https://doi.org/10.1590/ S0103-40141997000300013 
DAMAŠKA, Mirjan. Structures of Authority and Comparative Criminal Procedure. The Yale Law Journal, New Haven, vol. 84, n. 3, 1975. https://doi. org/10.2307/795463

DZUR, Albert W. Punishment, Participatory Democracy, and the Jury. Nova York: Oxford University Press, 2012. https://doi.org/10.1093/ acprof:oso/9780199874095.001.0001

FACCINI NETO, Orlando. A clemência e o Júri: uma tentativa de conciliação. In: FACCINI NETO, Orlando. Questões morais e direito penal: estudos reunidos (ePub). São Paulo: Saraiva, 2020.

FERRAJOLI, Luigi. Por Uma Teoria dos direitos e dos Bens Fundamentais. (ePub). Porto Alegre: Livraria do Advogado Editora, 2011.

GRECO, Luís. Strafjurist mit gutem Gewissen - Kritik der opferorientierten Straftheorie. Goltdammer's Archiv für Strafrecht, 2020.

GRECO, Luís. Strafprozesstheorie und materielle Rechtskraft: Grundlagen und Dogmatik des Tatbegriffs, des Strafklageverbrauchs und der Wiederaufnahme im Strafverfahrensrecht. Berlin: Duncker \& Humblot, 2015. https://doi. org/10.3790/978-3-428-54464-6

GUIMARÃES NETO, Silvio Leite. Uma teoria da pena baseada na vítima. A busca pela satisfação do indivíduo vitimado como finalidade da pena. São Paulo: Marcial Pons, 2020.

HARCOURT, Bernard E. Meditaciones postmodernas sobre el castigo: Acerca de los límites de la razón y de las virtudes de la aleatoriedad (una polémica y un manifiesto para el siglo XXI). Revista de Derecho Penal y Criminologia, Bogotá, n. 90, vol. XXXI, 2010. https://doi.org/10.5354/0718-4735.2011.29455

JACKSON, John D. Making Juries Accountable. The American Journal of Comparative Law, vol 50, n. 3, 2002. https://doi.org/10.2307/841060

KANT, Immanuel. Über den Gemeinspruch: Das mag in der Theorie richtig sein, taugt aber nicht für die Praxis. AA VIII, 1793.

KINGREEN, Thorsten; POSCHER, Ralf. Grundrechte Staatsrecht II. 36. ed. Heidelberg: C. F. Müller, 2020.

LEISNER, Walter. Das Volk: Realer oder fiktiver Souverän? Berlin: Duncker \& Humblot, 2005. https://doi.org/10.3790/978-3-428-51831-9

LOPES JR., Aury. Direito processual penal. 19. ed. (ePub). São Paulo: Saraiva, 2019. 
MAGER, Ute. Einrichtungsgarantien: Entstehung, Wurzeln, Wandlungen und grundgesetzgemäße Neubestimmung einer dogmatischen Figur des Verfassungsrechts. Tübingen: Mohr Siebeck, 2003.

MARTINELLI, João Paulo Orsini. Paternalismo jurídico-penal. Tese de doutorado. Faculdade de Direito. Universidade de São Paulo. São Paulo, 2010.

MAUNZ, Theodor; DÜRIG, Günter; HERDEGEN, Matthias (Org.): Grundgesetz. Kommentar. Munique: C.H. Beck, 2020.

MENDES, Gilmar Ferreira; BRANCO, Paulo Gonet. Curso de Direito Constitucional. 12. ed. São Paulo: Saraiva, 2017. https://doi.org/10.11117/9788502155077

MIRANDA, Jorge. Manual de Direito Constitucional. Tomo IV. 3. ed. Coimbra: Coimbra Editora, 2000.

NUCCI, Guilherme de Souza. Manual de Processo Penal e Execução Penal. 13. ed. (ePub). Rio de Janeiro: Forense, 2016.

NUCCI, Guilherme de Souza. Princípios Constitucionais Penais e Processuais Penais. 4. ed. (ePub). Rio de Janeiro: Forense, 2015.

OTT, Konrad. Moralbegründungen: zur Einführung. Hamburgo: Junius, 2001.

PALMA, Maria Fernanda. O princípio da desculpa em Direito Penal. Coimbra: Almedina, 2005.

PINKER, Steven. A History of Violence; We're getting nicer every day. Disponível em: <https://newrepublic.com/article/64340/history-violence-were-getting-nicer-every-day>. Acesso em: 02 mar. 2021.

PRINZ, Jesse. Constructive sentimentalism: legal and political implications. Nomos, Nova York, vol. 53, 2013. https://doi.org/10.18574/nyu/9780814760147.003.0001

RODRIGUES, Paulo Gustavo. Redefinindo o trânsito em julgado a partir da soberania dos veredictos: a coisa julgada parcial no tribunal do júri. Revista Brasileira de Direito Processual Penal, Porto Alegre, v. 6, n. 2, 2020. https://doi.org/10.22197/ rbdpp.v6i2.301

ROXIN, Claus. Política criminal e sistema jurídico-penal. Rio de Janeiro: Renovar, 2002.

ROXIN, Claus; GRECO, Luís. Strafrecht Allgemeiner Teil. Bd I. 5. ed. Munique: C.H. Beck, 2020. https://doi.org/10.17104/9783406758010

ROUSSEAU, Jean-Jacques. Du contrat social. Paris: Chez Mourer et Pinparé, 1797. 
RUSSELL, Bertrand. History of Western Philosophy. Abingdon: Routledge, 2004. SANDEL, Michael J. Justice: what's the right thing to do? Nova York: Farrar, Straus and Giroux, 2009.

SARLET, Ingo. A Eficácia dos Direito Fundamentais: Uma Teoria Geral dos Direitos Fundamentais na Perspectiva Constitucional. 12. ed. Porto Alegre: Livraria do Advogado, 2015.

SILVA JARDIM, Eliete. Tribunal do Júri - absolvição fundada no quesito genérico: ausência de vinculação à prova dos autos e irrecorribilidade. Revista EMERJ, Rio de Janeiro, v. 18, n. 67, 2015.

SILVA, José Afonso da. Curso de Direito Constitucional Positivo. 25. ed. São Paulo: Malheiros, 2005.

STRECK, Lenio Luiz. Júri: pode um simples “não" levar à imediata prisão do réu? Disponível em: <https://www.conjur.com.br/2020-jan-30/senso-incomum-juri-simples-nao-levar-imediata-prisao-reu>. Acesso em: 02 mar. 2021.

TOLKIEN. John R. R. The Return of the King. Quality Paperback Book Club, 2001.

TOCQUEVILLE, Alexis de. De la démocratie en Amérique. Tomo I e II. Breslávia: Nouvelles Lectures d'Antan, 2019.

TRINDADE, André Karam; STRECK, Lenio Luiz. Júri não pode absolver porque quer ou porque sim. Nem condenar. Disponível em: https://www.conjur.com. br/2016-jun-18/diario-classe-juri-nao-absolver-porque-ou-porque-sim-nem-condenar. Acesso em: 02 mar. 2021.

VELOSO, Caetano. Livros. Livro. Polygram, 1997.

VIEIRA, Renato Stanziola. Paridade de armas no processo penal: do conceito à aplicação no direito processual brasileiro. Dissertação de Mestrado. Faculdade de Direito. Universidade de São Paulo. São Paulo, 2013.

VON HIPPEL, Robert. Deutsches Strafrecht. Bd. 2. Berlim: Springer, 1971. https:// doi.org/10.1007/978-3-642-52599-5

WOLIN, Sheldon S. Norm and form. In: WOLIN, Sheldon S. Fugitive democracy: and other essays. Nova Jersey: Princeton University Press, 2016. https://doi. org/10.23943/princeton/9780691133645.003.0005

WRANGHAM, Richard. Killer Species. Daedalus, Cambridge, vol. 133, 2004. https://doi.org/10.1162/0011526042365573 


\section{Informações adicionais e declarações dos autores (integridade científica)}

Agradecimentos (acknowledgement): Felipe de Lorenzi, Izabele Kasecker, Lucas Montenegro, Luís Greco, Orlandino Gleizer, Ronan Rocha, pela revisão e comentários.

Declaração de conflito de interesses (conflict of interest declaration): o autor confirma que não há conflitos de interesse na realização das pesquisas expostas e na redação deste artigo.

Declaração de autoria e especificação das contribuições (declaration of authorship): todas e somente as pessoas que atendem os requisitos de autoria deste artigo estão listadas como autores; todos os coautores se responsabilizam integralmente por este trabalho em sua totalidade.

Declaração de ineditismo e originalidade (declaration of originality): o autor assegura que o texto aqui publicado não foi divulgado anteriormente em outro meio e que futura republicação somente se realizará com a indicação expressa da referência desta publicação original; também atesta que não há plágio de terceiros ou autoplágio. 
Dados do processo editorial

(http://www.ibraspp.com.br/revista/index.php/RBDPP/about/editorialPolicies)

- Recebido em: 26/11/2020

Equipe editorial envolvida

- Controle preliminar e verificação de plágio:

- Editor-chefe: 1 (VGV) 02/12/2020

- Avaliação 1: 21/12/2020

- Editor-assistente: 1 (TAJ)

- Revisores: 3

- Avaliação 2: 22/12/2020

- Avaliação 3: 08/01/2021

- Decisão editorial preliminar: 24/02/2021

- Retorno rodada de correções: 04/03/2021

- Decisão editorial final: 19/04/2021

\section{COMO CITAR ESTE ARTIGO:}

SOARES, Hugo. Clemência no Tribunal do Júri? Reflexões derivadas do argumento a fortiori trazido no voto-vogal do Min. Fachin em sede do ARE 1225185, Tema/RG 1.087. Revista Brasileira de Direito Processual Penal, Porto Alegre, vol. 7, n. 2, p. 1513-1546, mai./ago. 2021. https://doi.org/10.22197/rbdpp.v7i2.468

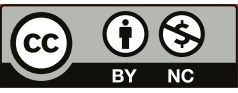

Esta obra está licenciada com uma Licença Creative Commons Atribuição-NãoComercial 4.0 Internacional. 